15.

\title{
„VI NA BALKANU TO SVE ZNATE I \\ ČITATE?!“ RECEPCIJSKA ČITANJA \\ I UPOTREBE JULIENA BENDE I \\ IZDAJE INTELEKTUALACA
}

\section{Branimir Janković}

UDK: 130.2Benda, J.“192“:316.74

Izvorni znanstveni članak

Sažetak: Rasprava Izdaja intelektualaca (La Trahison des clercs) francuskog filozofa, književnika i pisca Juliena Bende iz 1927. godine sačuvala je do danas status gotovo najpoznatijeg djela koje razmatra ulogu intelektualaca, napose zbog zaoštrene teze da su intelektualci izdali svoje univerzalno poslanje pristajući uz državne, nacionalne, klasne i druge partikularizme. Knjiga je u Makedoniji, Srbiji i Hrvatskoj prevedena tek 1990-ih godina, ali je njezina recepcija bila istovremena s objavljivanjem izvornika. Posebno se u tome izdvaja Bogdan Radica, koji je o Julienu Bendi pisao već od 1928. godine. U radu se prate smjerovi hrvatskih i regionalnih recepcijskih čitanja i upotrebljavanja Bendine znamenite teze o izdaji intelektualaca u rasponu od međuratnog razdoblja do neposredne suvremenosti. Time se ukazuje na reprezentativna mjesta domaćeg konteksta poimanja intelektualaca i dominantnih obilježja matične intelektualne povijesti budući da je aktivna recepcija i aproprijacija J. Bende i teze o izdaji intelektualaca tema intelektualne povijesti par excellence. Pritom se cirkuliranje Bendinih ideja i tekstova - kao činova kulturnih transfera - promatra kroz poticajne uvide francuskog sociologa Pierrea Bourdieua o „društvenim uvjetima međunarodne cirkulacije ideja“.

Ključne riječi: intelektualci, izdaja intelektualaca, Julien Benda, Bogdan Radica, recepcija, upotreba, Pierre Bourdieu

itirane riječi iz naslova izrekao je u Parizu 1939. godine francuski filozof, književnik i pisac Julien Benda, komentirajući poznavanje i čitanje njegovih djela o ulozi intelektualaca u razgovoru s njime objavljenom 1940. godine u poznatoj knjizi Agonija Evrope Bogdana Radice. Iako smo danas (kao rezultat kritičke analize orijentalističkih i balkanističkih diskursa) senzibilizirani za dekodiranje sličnih sudova koji asimetrično vrednuju kulturnog Drugog, navedene riječi mogu istodobno poslužiti za naglašavanje aktivne recepcijske perspektive u kojoj će se promatrati Julien Benda i napose njegova poznata teza o „izdaji intelektualaca“. Teza koja je iznimno uspješno prelazila kulture i vremenska razdoblja. 
Istoimena rasprava Izdaja intelektualaca (La Trahison des clercs), objavljena 1927. godine, do danas je sačuvala status gotovo najpoznatijeg djela koje razmatra ulogu intelektualaca i njihovu društtvenu odgovornost, posebice zbog zaoštrene teze da su intelektualci izdali svoje univerzalno poslanje pristajući uz državne, nacionalne, klasne i druge partikularizme. Knjiga je u Makedoniji, Srbiji i Hrvatskoj prevedena tek 1990-ih godina, ali je njezina recepcija bila istovremena s objavljivanjem izvornika. Osim Bogdana Radice, koji je o Julienu Bendi pisao od 1928. godine, moguće je u međuratnom i kasnijim razdobljima pratiti i druge hrvatske i regionalne recepcijske tragove J. Bende i njegove znamenite teze, što uključuju i prijevode njegovih tekstova, a naposljetku i knjige. Time navedena problematika - uz splitsku pozadinu po B. Radici - ima dakako širi prostorni i kulturni obzor.

Pritom praćenje smjerova „poznavanja i čitanja“ Bendine Izdaje intelektualaca neosporno ukazuje na reprezentativna mjesta domaćeg poimanja intelektualaca i čini slojeviti dio matične intelektualne povijesti. Aktivna recepcija i aproprijacija Juliena Bende i njegove teze o „izdaji intelektualaca“ tema je intelektualne povijesti par excellence. Osim intelektualne povijesti, riječ je naravno i o povijesti intelektualaca, ne samo po tome što se tematizira kritička ocjena suvremenih intelektualaca u vidu naglašavanja njihove „izdaje“, nego i zbog toga što takvu kritičku ocjenu prenose i prisvajaju osobe koje se i same percipiraju intelektualcima. Počevši od Radice i nastavljajući do suvremenih autora, radi se o osobama koje bez obzira kojoj profesiji pripadali (uglavnom su to umjetnici, književnici, novinari, znanstvenici) dijele zajednički status intelektualaca ili imaju društvenu funkciju intelektualaca, neovisno o tome jesu li se i sami takvima doživljavali. ${ }^{1}$

U međuratnom i ratnom razdoblju 20. stoljeća, koje čine vremenski okvir ovog zbornika, pojmovi intelektualac/intelektualci, odnosno inteligencija, jako se često koriste. U predratnim, ratnim i poslijeratnim periodima inače se pridaje velika važnost intelektualcima i njihovoj ulozi i odgovornosti. Ta su vremena stoga posebno prijemčiva za govor o ,izdaji intelektualaca“. No, neovisno od toga, ispostavlja se da je to s vremena na vrijeme uvijek aktualna tema u javnosti, bez obzira kako se vrednuje problematika javnih intelektualaca $\mathrm{i}$ intelektualnih intervencija. $\mathrm{O}$ tome svjedoče kontinuirana pozivanja na Bendu ne samo među autorima prve polovice 20. stoljeća, nego i među suvremenim intelektualacima u $\mathrm{Hr}$ vatskoj i regiji sve do danas. Iako je problematika intelektualaca i njihove društvene uloge i odgovornosti tema koja je u bitno promijenjenim uvjetima druge polovice 20. i prve polovice 21. stoljeća izgubila svoju nekadašnju težinu, redovitost periodičkog pojavljivanja u javnosti još uvijek ne prestaje.

Premda, dakle, zadržava svoju aktualnost i relevantnost, navedenoj je povijesnoj i suvremenoj tematici potrebno dati - u znanstvenom polju - nove istraživačke perspektive i dodatnu problemsku životnost novim konceptualnim osnovama. S obzirom na to, za spomenutu problematiku recepcije i aproprijacije koja polazi od cirkuliranja Bendinih ideja i

\footnotetext{
Isto tako treba imati u vidu da su osobe koje se obrađuje u ovom zborniku (Vladan Desnica, Ivan Meštrović, Bogdan Radica, Kerubin Šegvić, Tin Ujević, Benedetto Croce, Luigi Pirandello, André Gide i mnogi drugi), bez obzira kojoj profesiji pripadali, ujedno i intelektualci, dakako u različitim rasponima samopoimanja i prakticiranja takvog položaja i uloge. Riječ je o aspektu koji se nerijetko zanemaruje budući da je fokus često na razmatranju njihovih djela ili biografije. Stoga ovaj rad o Bendi i Radici svojom problematikom nastoji nadići spomenutu dvojicu i implicitno uključiti i druge pojedince i intelektualne krugove koje se analizira u zborniku.
} 
tekstova - kao činova kulturnih transfera - smatram poticajnim uvide francuskog sociologa Pierrea Bourdieua, posebice o „društvenim uvjetima međunarodne cirkulacije ideja“.

\section{POLAZIŠTA}

Usprkos u naslovu izdvojenog usklika iznenađenja Juliena Bende „Vi na Balkanu to sve znate i čitate?!“, bilo bi zapravo čudno da nije bilo recepcijskih odjeka. Naime njegovo glasovito djelo i poznata teza o izdaji intelektualaca iz 1927. godine imali su među suvremenicima znatan odjek. Navedeno možemo ilustrirati Radičinom napomenom: „Benda je prvi među svojim kolegama imao odvažnosti pred licem poljuljane Francuske i iscrpljene Europe iznijeti u kirurškom presjeku optužbu cijele jedne duhovnosti riječima koje su danas vlasništvo cijelog kulturnog Zapada: 'Izdaja vođa'."2 Značenje je vidljivo i u riječima Wolfa Lepeniesa da „nijedna knjiga u 20. stoljeću nije toliko utjecala na debatu o ulozi intelektualaca kao što je to učinila Bendina Izdaja intelektualaca". ${ }^{3}$

Sama je teza, odnosno naslovna sintagma o izdaji intelektualaca i danas često navođena u javnom govoru. Jedan od preduvjeta svakako je u tome što ima sve ono što je potrebno da osigura spominjanje teze čak i bez obzira na čitanje i poznavanje djela. Kao što je napomenuo Bourdieu koji je konceptualna osnova ovog rada - „velika proročanstva su višeznačna"i stoga takvi autori uspješno

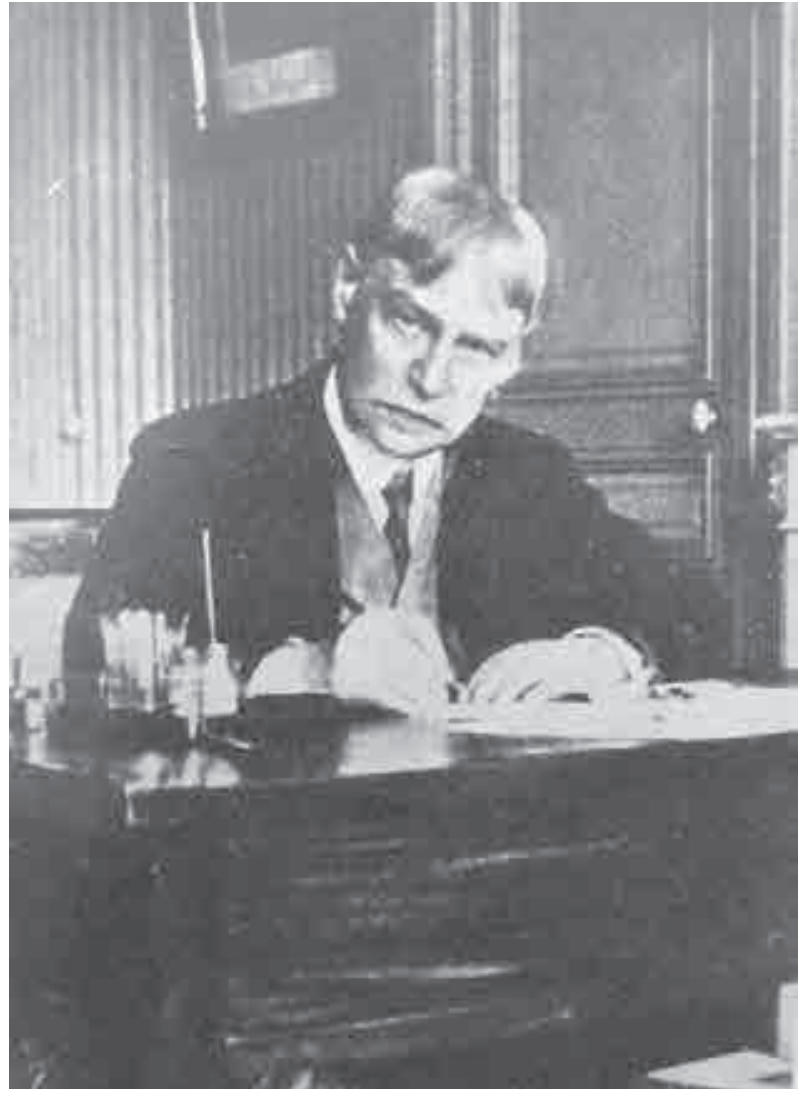

Sl. 1. Julien Benda cirkuliraju i s lakoćom prelaze prostorne granice i vremenska razdoblja jer su značenjski rastezljivi i podložni interpretativnim pripisivanjima i upotrebama. ${ }^{4}$ To dakako znači da

2 Bogdan Radica, Agonija Europe. Razgovori i susreti, Zagreb 2006., 176. U citiranju ću koristiti zagrebačko izdanje iz 2006. godine. Knjiga Agonija Evrope. Razgovori i susreti objavljena je izvorno u Beogradu 1940. godine.

3 Citirano prema: Rade KalanJ, „Uvijek prijeporni Benda“ (pogovor), u: Julien Benda, Izdaja intelektualaca, Zagreb 1997., 196.

4 Pierre Bourdieu, „Društveni uvjeti međunarodne cirkulacije ideja“, Intelektualna historija (prir. Branimir Janković), Zagreb 2013., 117. 
svatko u njima može isticati nešto drugo, prilagođeno osobnim i lokalnim potrebama, odnosno priželjkivanim smjerovima aproprijacije.

Neovisno o tome gdje sve i kada sve Bendinu tezu možemo zateći u upotrebi, on sam ju je 1927. godine i kasnije odredio kao izdajstvo intelektualaca u smislu njihovog napuštanja univerzalnih vrijednosti nauštrb državnih, nacionalnih, klasnih i drugih partikularizama. Intelektualci bi umjesto toga trebali biblijski reći: Moje kraljevstvo nije od ovoga svijeta. Posvećenost koja njima priliči tiče se razuma, pravde i istine, a u kontekstu zaoštrenog razdoblja između dva svjetska rata to se odnosi i na pristajanje uz demokraciju. Iz navedenog proizlazi protivljenje izravnom angažmanu intelektualaca. ${ }^{5}$

Naglašavam da mi nije ovdje cilj ulaziti detaljnije u samu Bendinu argumentaciju, kao i tumačenja ili kritička vrednovanja njegove teze i pripadajućih postavki, ${ }^{6}$ već ponajprije razmatrati kako se Benda i njegove ideje recipiraju i upotrebljavaju te $s$ kojom svrhom. U jednu riječ, moguće je zapitati se na tragu primjera koji navodi Bourdieu - naime da je u poslijeratnoj Francuskoj bio toliki interes za Heideggera zato što je korišten protiv tada dominirajućeg Sartrea ${ }^{7}$ - protiv koga je ili za koga intelektualno uvođen Benda u međuratnoj Jugoslaviji?

Zbog toga je osim evidentiranja recepcije i čina kulturnog transfera potrebno ipak nastojati ići još dalje. Polazim, naime, od pretpostavke da nije dovoljno reći da je postojala znatna recepcija Bende kojoj govore u prilog različiti primjeri. U tom je smislu moguće navesti - rečeno geografskim okvirom Desničinih susreta - da je slovenski povjesničar Fran Zwitter 1933. godine obavijestio o Bendinoj knjizi Izdaja intelektualaca, ${ }^{8}$ da je crnogorska Slobodna misao prevela Bendin tekst „Kultura i inteligencija“ 1935 . godine, ${ }^{9}$ da je Nova Evropa prevela 1936. godine njegov tekst „Podvojena Francuska“, ${ }^{10}$ da je hrvatski književnik Ivan Goran Kovačić preveo Bendin tekst „Književnost ne može biti vazal filozofije i nauke" 1938. godine, ${ }^{11}$ kao i da je Benda zastupljen u Razgovoru o Europi objavljenom 1944. godine. ${ }^{12}$ Osobito se pritom ističu brojni prilozi Bogdana Radice, prvenstveno o poimanju intelektualaca i pitanju njihove uloge. ${ }^{13}$

No, trebalo bi osim detektiranja recepcije zahvatiti i problematiku upotrebe i prisvajanja. U tome držim posebno korisnim sociološke analize Pierrea Bourdieua, pri čemu se oslanjam na ovdje već spomenute, kao i na druge uvide iz njegovog teksta „Društveni uvjeti

\footnotetext{
Usp. J. BendA, Izdaja intelektualaca, kao i pogovor R. Kalanja.

Za više o tome usp. spomenuti pogovor R. Kalanja.

P. Bourdieu, „Društveni uvjeti međunarodne cirkulacije ideja“, 116.

Fran Zwitter, „Julien Benda“, Sodobnost, 1/1933., br. 1, 45-47.

9 Jules Benda, „Kultura i inteligencija“, Slobodna misao (Nikšić), br. 37, 27. 10. 1935., 3-4.

10 Julien Benda, „Podvojena Francuska“, Nova Evropa, 29/1936., br. 5, 134-141.

11 Julien BENDA, „Književnost ne može biti vazal filozofije i nauke“, Hrvatski dnevnik, 3/1938., br. 951, 36.

12 Razgovor o Europi. Kulturno-politički eseji francuskih pisaca (prir. Ivo Hergešić), Zagreb 1944.; Osijek 1997. Navodim i: Julien Benda, „Govor europskoj naciji“",Europski glasnik, 18/2013., 193-206.

13 Bogdan Radica, „Ideje Julijena Bende“, Savremenik, 21/1928., br. 2, 50-55; „Izdajstvo uma“, Obzor (Zagreb), br. 74, 15. 3. 1928., 2-3; „'Izdajstvo vođa’ (Svedočanstvo najmlađih)“, Nova Evropa, 18/1928., br. 6, 186-189; „Konac vječnoga. Teza Juliena Bende i protest Jeana Guéhenna“, Hrvatska revija, 2/1929., br. 6, 358-364, pretiskano i u: Novo doba (Split), br. 145, 10. 6. 1929., 2, 7; br. 146, 11. 6. 1929., 2; „Žilijen Benda o Masariku (Vodj koji nije zatajio)“, Nova Evropa, 21/1930., br. 4, 234-235. Za referiranja na Bendu u drugim člancima usp. Agonija Europe, 387-388. U to, naravno, ulazi Radičin razgovor s Bendom i prilog o njemu u Agoniji Evrope 1940. godine.
} 
međunarodne cirkulacije ideja“. Tekst „Les conditions sociales de la circulation internationale des idées“ iz 1990. godine, koji može biti shvaćen kao programatski, višekratno je objavljivan, a na hrvatski jezik preveden 2013. godine. ${ }^{14}$

Bourdieu u tekstu - koji je tek jedan dio njegovih šire zamišljenih analiza - razmatra cirkuliranje autora, tekstova i ideja između različitih intelektualnih polja, na primjer francuskog i njemačkog. Pritom raščlanjuje proces transfera tekstova i djela iz domaćeg u strano polje, dakle iz polja proizvodnje u polje recepcije, koji su, dakako, kontekstualno različiti. To se može ilustrirati primjerom da "netko tko je autoritet u svojoj zemlji ne iznosi taj autoritet sa sobom “. ${ }^{15}$ Bourdieu ističe da se prilikom čina transfera odvija niz operacija poput operacije selekcije (primjerice izbora onoga što se prevodi), operacije obilježavanja (primjer predgovorom) i operacije čitanja (polazeći od toga da čitatelj uneseno djelo iz stranog polja čita na tragu preokupacija vlastitog, domaćeg polja).

Upozorava potom na interes prisutan u recipiranju i prevođenju/uvođenju određenog djela, polazeći od pretpostavke „kako svatko tko aproprira autora, postajući osoba koja tog autora predstavlja, uz najbolju volju, ipak ima neku osobnu dobit“. ${ }^{16}$ Navodi kako je katkad interesno polazište sadržano u sličnim pozicijama u različitim poljima, stoga se prisvajanjem određenog autora nastoji osnažiti vlastita pozicija u svom polju, bez obzira bila ta pozicija ugrožena ili dominirajuća. Zbog činjenice da se „aproprijacijom profitira“ moguće je primijetiti da su „heretički uvozi često (...) djelo marginaliziranih u polju, koji uvoze poruku, poziciju snage iz nekoga drugog polja, kako bi ojačali vlastitu podređenu poziciju unutar polja“. S druge strane, moguće je koristiti stranog autora protiv domaćih autora, pri čemu su strani autori „,̌esto predmetom vrlo instrumentaliziranih upotreba te se koriste za ciljeve koje bi možda i osudili“. ${ }^{17}$

Osim potrebe okretanja novim konceptualnim pristupima tu je i potreba za novim pitanjima u vezi problematike poimanja intelektualaca i njihove uloge, za što dodatno opravdanje daju i obilježja domaće literature o povijesti intelektualaca. Ima, dakako, u Hrvatskoj, Srbiji i Sloveniji znatan broj radova koji se izravno bave intelektualcima, primjerice u međuratnom razdoblju, ali pritom - prema mom uvidu - prevladava fokus na njihovim biografijama i djelovanju, kao i odnosu prema tada zaoštrenim nacionalnim i socijalnim pitanjima. ${ }^{18}$ Pritom se uglavnom više govori o idejama koje su intelektualci promicali i onome što su činili i kako su djelovali nego o ulozi koju su imali i koju im se pridavalo te kako su načelno, i eventualno u određenoj mjeri teorijski, razmatrali tu ulogu, odnosno jesu li se doživljavali kao intelektualci koji imaju određenu misiju.

\footnotetext{
Usp. P. Bourdieu, „Društveni uvjeti međunarodne cirkulacije ideja“, 112.

Isto, 114 .

Isto, 115.

Isto, 116.

18 Navodim samo neka djela: Mladen Iveković, Hrvatska lijeva inteligencija 1918-1945., Zagreb 1970.; Zorica STIPETIĆ, Komunistički pokret i inteligencija. Istraživanja ideološkog i političkog djelovanja inteligencije u Hrvatskoj (19181945), Zagreb 1980.; Milosav Janićijević, Stvaralačka inteligencija međuratne Jugoslavije, Beograd 1984.; Stipe KLJAjıć, Intelektualci i hrvatski nacionalizam (1929. - 1945.), doktorski rad, Zagreb 2015. Treba napomenuti da Janićijević u sociološkom istraživanju, uz njihov odnos prema ideološkim pitanjima, govori i o strukturnim obilježjima međuratnih intelektualaca kao društvene elite.
} 
Osim toga, pretežnim dijelom izostaje i usmjeravanje na konceptualno zasnovano praćenje recepcije i aproprijacije tekstova i djela samih intelektualaca. Imajući u vidu da se pristup povijesti knjige i čitanja - osobito razgranat pod utjecajem istraživanja R. Darntona i R. Chartierea - usmjerava većinom na predmodernu, odnosno ranonovjekovnu povijest, vrijedi poticati njegovu primjenu na bavljenje modernom i suvremenom poviješću. U ovom ću radu stoga pokušati izvršiti svojevrsnu nadogradnju tog pristupa usmjeravanjem na suvremenu povijest, stavljajući naglasak na pitanje recipiranja i prisvajanja tekstova, ideja i autora, primjenjujući to u ovom trenutku tek na odabranom primjeru. Na taj se način, zajedno s već spomenutim uključivanjem Bourdieuovih analiza o društvenim okolnostima transnacionalnog cirkuliranja ideja - na osnovi tako zasnovane konceptualizacije i istraživačkih pitanja - smjera ne samo prema povijesti intelektualaca, nego, zapravo, prema široj intelektualnoj povijesti. ${ }^{19}$

\section{RAdičina upotreba BENDE}

Spomenuti konceptualni okvir sadrži mnogo poticaja (i širenja perspektiva) koje možemo primijeniti na niz autora, tekstova i tema. Bilo u slučaju Bende, bilo na primjeru Crocea i Gidea, što ih se također spominje u ovom zborniku. Osim usmjeravanja na navedene ili na neke druge intelektualce i njihove ideje koje su predmetom upotrebe, potrebno je, dakako, analizirati i same autore koji upotrebljavaju, primjerice, Bendu i Crocea. Time smo došli do direktne veze sa Splitom - teme ovog zbornika - iako je njegova povijest intelektualaca i intelektualna povijest implicitno i univerzalno prisutna u svemu dosad iznesenom, što može načelno vrijediti i za druge mikrohistorijske i komparativne slučajeve. Veza sa Splitom očituje se u splitskom porijeklu Bogdana Radice (1904. - 1993.), koji je mnogo pisao o Bendi u raznim časopisima i novinama, među njima i u splitskim novinama Novo doba.

I dok je Bendina rasprava Izdaja intelektualaca izašla u Parizu u kolovozu - studenom 1927. godine, Radica je o Bendi i njegovoj tezi pisao već početkom 1928. godine - u veljači u Savremeniku i ožujku u Obzoru (1928. godine bio je dopisnik Obzora u Parizu). Radica je objavio nekoliko članaka o „idejama Juliena Bende“ i „tezi Juliena Bende“, koji su podloga, zajedno s razgovorom s njime iz 1939. godine, za poglavlje o Bendi objavljeno u Agoniji Evrope u Beogradu 1940. godine. Radica u svojim prikazima Bendine teze u spomenutim člancima iz 1928. i 1929. godine navodi njezine najvǎnije odrednice: izdaja intelektualaca je u pristajanju uz državne, nacionalne, klasne i druge partikularizme umjesto uz univerzalne vrijednosti. Pritom izdvaja Bendinu kritiku što su intelektualci (klerici) „sišli na trgove neukusnog političkog života i pomiješali se medju zamazane redove lajika“, ${ }^{20}$ odnosno po-

19 Činim to kao nastavljanje na publikaciju Intelektualna historija, koju smo u sklopu Desničinih susreta objavili 2013. godine budući da su se oni tih godina izrijekom bavili intelektualcima (temama intelektualaca i rata, kao i intelektualca danas). U toj smo publikaciji preveli spomenuti Bourdieuov tekst „Društveni uvjeti međunarodne cirkulacije ideja“.

20 Bogdan RadicA, „Ideje Julijena Bende“, Savremenik, 21/1928., br. 2, 52. 
miješali se s masom. Benda, prema Radici, uvjerljivo prikazuje dijagnozu duhovne situacije suvremene Francuske i Europe, obilježene napetošću i krizom (pri čemu je „fatalni August 1914. bio jedan od najstrašnijih kataklizama ove neprestano otvorene svjetske krize“21) te sveopćom prevlašću politike.

Radica drži Bendu jednim od najistaknutijih intelektualaca Francuske, koji iznosi „najdisparatnije probleme evropske sadašnjice i postavlja ih u perspektivu univerzalnog posmatranja“. ${ }^{22}$ Navodi da Benda, premda osamljen, svojim tezama privlači europsku elitu. Za Radicu, na općoj razini, u „današnjim odnosima glas Bende služi kao poziv na povratak redu, mjeri, t. j. klasicizmu“, 23 uz „njegovu bitnu težnju za harmonijom, za redom, za smirenjem, za objektivnošću i za klasičnim savršenstvom “. ${ }^{24}$ Napominjem da su, na osnovi takvih i drugih sličnih argumentacija, kasniji istraživači uključivali Bendu u antimodernističke mislioce. ${ }^{25}$

No, dok je krajem 1920-ih godina još bilo moguće zazivati opću duhovnu revoluciju, odnosno preporod, deset godina kasnije, kada Radica 1939. godine vodi razgovor s Bendom objavljen u Agoniji Evrope, na dnevnom je redu žurna potreba direktnog angažmana. Radica tako piše kako je Benda „zalupio (...) vrata kuli bjelokosnoj u koju je htio uzidati savršen tip intelektualca i vratio se svijetu, čovječanstvu, društvu i njegovoj borbi“ ${ }^{26}{ }^{26}$ Sažeo je to u izrazu: „Julien Benda sišao je na ulicu (... “), ${ }^{27}$ što je ključan Bendin motiv koji Radica preuzima i u svojim kasnijim zapisima. Iako su članci podloga za uvod u razgovor s Bendom, treba dakle razlikovati Radičino pisanje o Bendi krajem 1920-ih i krajem 1930-ih godina.

Razlike ipak nisu fundamentalne, već su sadržane u nijansama, kako su se već događale promjene s Bendinim djelovanjem kao rezultatom intenziviranja predratnih okolnosti u Europi, koje su, dakako, iznimno mnogo utjecale i na Radicu. Dramatična prijeratna i ratna zbivanja označavala su apostrofirani Bendin silazak na ulicu i spuštanje na trg te upuštanje u borbu, uz njegovo stalno osuđivanje francuske i europske građanske klase, kao i zagovaranje demokracije koja će se boriti protiv dvaju totalitarizama (fašističkog i komunističkog). Pritom je Bendin odnos prema komunizmu uz kritiziranje prolazio i kroz faze podržavanja i približavanja, kao i odmicanja. ${ }^{28}$ I sam je Radica u kontekstu rata pokazao spremnost prihvaćanja važnosti izravnijeg angažiranja.

Većinom je u Radičinim tekstovima o Bendi (koji su zaista detaljna obavijest o njegovoj biografiji i djelu) u prvom planu iznošenje Bendinih ideja, dok je Radičinih osvrta na hrvatski i jugoslavenski kontekst, odnosno domaće intelektualno polje malo. Usprkos tome može se postaviti pitanje koji je, rečeno Bourdieuom, interes Radice za pisanjem o Bendi? Treba imati u vidu da je Radica kada je počeo pisati o Bendi vrlo mlad, naime 1928. godi-

21 Bogdan RadicA, „Konac vječnoga. Teza Juliena Bende i protest Jeana Guéhenna“, Novo doba (Split), br. $145,10.6$. 1929., 7.

22 B. RadicA, „Ideje Juliena Bende“, 50.

23 Isto, 55.

24 Bogdan RadicA, „Izdajstvo uma“, Obzor (Zagreb), br. 74, 15. 3. 1928., 2.

25 Usp. Antoine Compagnon, Les antimodernes. De Joseph de Maistre à Roland Barthes, Paris 2005.

26 B. RadicA, Agonija Europe, 177.

27 Isto, 178.

28 Isto, 178-181; R. KALANJ, „Uvijek prijeporni Benda“, 195-196. 
ne imao je nepune 24 godine. No, postojeće rekonstrukcije Radičina političkog puta, kao i njegova memoaristika, omogućuju određene zaključke. Sažeto rečeno, literatura naglašava da je Radica u razdoblju između dva svjetska rata blizak europskim liberalnim intelektualcima koji dijele „opasnost nadirućeg lijevog i desnog totalitarizma“. ${ }^{29}$ Sam je Radica sebe memoarski vidio na tadašnjoj poziciji „,između dva totalitarizma, fašizma i komunizma“, 30 naglašavajući: „Ne učestvovati u toj drami, ni na jednoj, ni na drugoj strani, ni na nacističko-fašističkoj, ni marksističkoj alternativi, moralo je značiti biti usamljen. “31

Uzimajući sve u obzir moguće je zaključiti da Radica - na tragu Bourdieuovih napomena - koristi Bendu kao dodatni argument za ojačavanje vlastite pozicije sadržane u svom međuratnom odbijanju i ideje fašizma i ideje komunizma: ne pristajanja, dakle, uz izrazite nacionalne i klasne partikularizme. Također u skladu s Bourdieuovim uvidima, primjetno je da Radica koristi Bendu kao stranog autora protiv domaćih angažiranih intelektualaca. To vrijedi napose za Krležu, prema kojem će Radica biti osobito kritičan. ${ }^{32}$ Osim toga, naravno da je za Radicu pisati o Bendi (i drugim tadašnjim poznatim europskim intelektualcima) imalo prestiž, odnosno rečeno Bourdieuom, značilo prisvajanje simboličkog kapitala francuskog intelektualca koji je izazvao znatnu pozornost svojom raspravom.

Pred Drugi svjetski rat i samom se Radici nametnulo pitanje direktnijeg angažmana, kao što je to slučaj s Bendom. Dok se Bendino djelo inicijalno suprotstavljalo angažmanu, njegova kasnija biografija itekako će ga uključivati. Za Radicu će Benda imati dakle značenje kako svojim djelom, tako i pitanjem vlastitog pozicioniranja, odnosno angažiranja. To nije, naravno, samo Bendino ili Radičino preispitivanje, već dvojba za mnoge tadašnje europske intelektualce. Zaoštreno međuratno razdoblje (koje je istovremeno i poslijeratno i predratno) sve intenzivnije je stavljalo na dnevni red pitanje angažirati se ili ne, ostati izvan politike i držati se kakve univerzalne pozicije (u Bendinom smislu) ili pak izravnije ući u političku borbu. Odgovori su bili vrlo različiti. Kao primjer možemo uzeti intelektualce s kojima je Radica razgovarao u Agoniji Evrope - José Ortegu y Gasseta i Miguela de Unamuna. ${ }^{33}$

Za J. Ortegu y Gasseta uloga intelektualca pred Drugi svjetski rat nije u „sudjelovanju u duhovnoj i u političkoj borbi koja vlada svijetom i Europom“. Nasuprot tome, „intelektualac treba stajati izvan sukoba i izvan sajmišta“. Jedan od razloga za to je, prema Ortegi y Gasseti, u kompromitiranju intelektualaca „i u Europi i u pojedinim zemljama baš zbog toga što su htjeli sudjelovati u borbi i što su pristali pokazati se $s$ jedne ili druge strane barikade “ ${ }^{34}$ Njegovo naglašavanje („Ostati izvan borbe - to je cilj i smisao intelektualca. ${ }^{(35}$ ) ipak je su-

\footnotetext{
29 Stevo ĐurašKović, „Bogdan Radica - nacionalist, liberal i kozmopolit istodobno“, u: Bogdan Radica, Agonija Europe. Razgovori i susreti, Zagreb 2006., 381. Usp. i Ivo BANAC, „Bogdan Radica - agonija i borba“, Agonija Europe, 372.

30 Bogdan Radica, Živjeti nedoživjeti, knj. 1: Uspomene hrvatskog intelektualca kroz moralnu i ideološku krizu Zapada, München - Barcelona 1982., 10.

$31 \quad$ Isto, 652.

32 Isto, 101-103; Stanko Lasić, Krležologija ili povijest kritičke misli o Miroslavu Krleži, sv. 6, Zagreb 1993., 162-169, $300-301$.

33 Njihovo suprotno poimanje u kontekstu Radičina angažmana naveo je i I. Banac. Usp. I. BANAC, „Bogdan Radica“, 372.

34 B. Radica, Agonija Europe, 169.

35 Isto, 170.
} 
protno naizgled sličnom zagovaranju univerzalne pozicije intelektualca kakvu izriče Benda. Razlog tomu su brojni dodatni aspekti koje sadrži Bendina slojevita koncepcija intelektualca kao srednjovjekovnog klerika, ali još više što je Benda pred Drugi svjetski rat izricao potrebu angažiranja za demokraciju koja će se boriti, a ne se izmicati u vidu napomena Ortege y Gasseta. Stoga je Ortega y Gasset i mogao reći: „Ne slažem se ni s Bendom. “36

Nasuprot tome stoji M. de Unamuno, koji je, kako navodi Radica, sišao na ulicu, sišao „na trg, u agoru, u borbu grada i zemlje (...), u agoniju“. ${ }^{37}$ Za Unamuna je život „vječna i neprekidna borba" i stoga prezire mirovanje. ${ }^{38}$ To je, dakako, vidljivo u njegovom kompleksnom razvijanju koncepcije agonije kao stalne borbe. Zbog toga Unamuno logično „odbija Bendu i njegovu tezu o clercu; gleda na nju kao na promatranje života iz kule bjelokosne“.39 U opreci Ortega y Gasset - Unamuno, Radica je bliži potonjem. Primjerice, na tvrdnje Ortege y Gasseta kako se intelektualac ne bi trebao izravno angažirati u sukobima, Radica u razgovoru s njim odgovara protupitanjem: nije li „uloga intelektualaca ipak oduvijek bila u njihovu odupiranju vremenu i u otporu sili "“? 40 Nadalje, Radica u unamunovskom značenju naziva svoju knjigu upravo - Agonija Evrope. Od toga je dakako neusporedivo rječitije kasnije konkretno Radičino angažiranje. Naime, za vrijeme Drugog svjetskog rata Radica iz SAD-a počinje podupirati antifašistički partizanski pokret. Razočaravši se međutim završetkom rata u totalitarnu matricu komunističkog režima, odlazi 1945. godine iz Jugoslavije, nastavljajući u SAD-u kontinuirano pisati protiv njega.

Radičino pisanje o Bendi oprimjeruje uvid da su same ideje prilikom transfera podložne modificiranju i prilagođavanju. Tako Radica Bendin termin i tezu o „izdaji intelektualaca“ prevodi u nekoliko varijanti, a među njima posebno često kao „izdaju vođa“. Francuski izvornik polazi od termina $\operatorname{clerc,~u~značenju~klerika,~zbog~Bendina~priželjkivanog~poimanja~}$ intelektualca kao srednjovjekovnog klerika koji je bio posvećen univerzalnom i transcendentalnom. Pojam intelektualca bio je, dakako, u optjecaju tada u Francuskoj, ali Benda namjerice radi značenjski pomak prema kleriku. To u pozadini zrcali njegovo razočaranje u suvremene francuske intelektualce i građanstvo u cjelini - koje optužuje za izdaju - zbog čega poseže za prošlošću, nalazeći u njoj primjere kada su, prema njegovom mišljenju, intelektualci svoj poziv poimali bitno univerzalnije nego u suvremenosti.

Usprkos tomu, uobičajilo se Bendin središnji termin klerika i pripadajuće djelo prevoditi kao intelektualca, odnosno „izdaju intelektualaca“, na što se zapravo i referiraju. ${ }^{41}$ Odlučiti se u prevođenju na zadržavanje izvornog termina klerika izgubilo bi, dakle, poruku izdaje intelektualaca, no moglo bi u određenim prigodama imati značenje za religijsku problematiku. Teza bi tada - u skladu s Bendinom argumentacijom - poticala aktualiziranje $u$ vidu pitanja je li svećenstvo umjesto univerzalnog i transcendentalnog suviše pristalo uz nacionalni partikularizam.

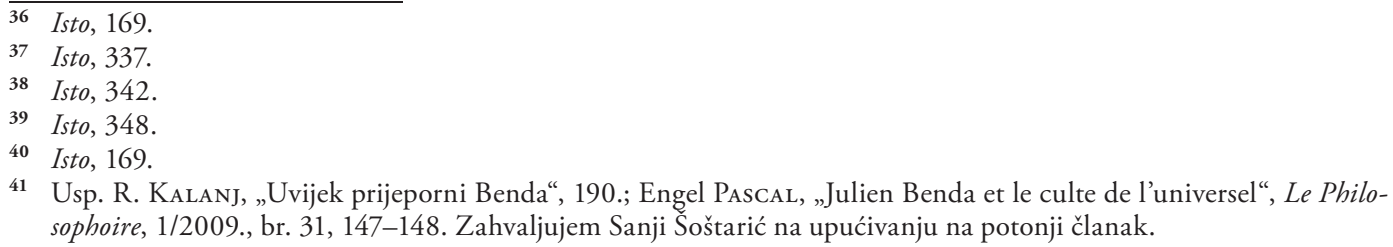




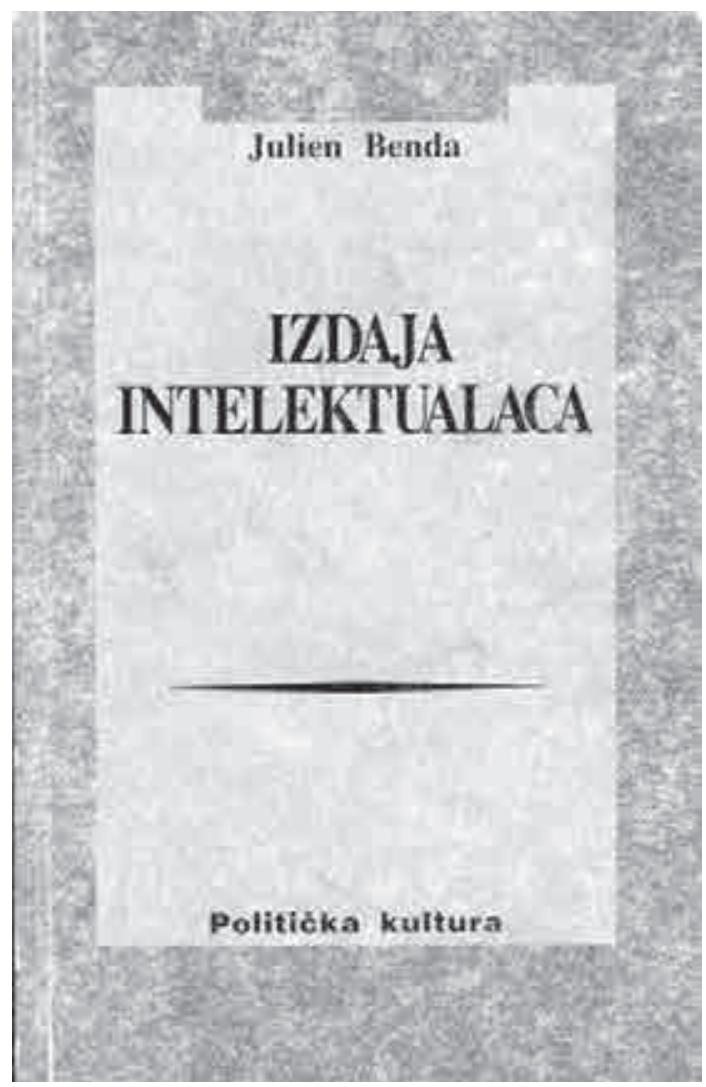

Sl. 2. Naslovnica hrvatskog izdanja Bendine Izdaje intelektualaca (1997.)

Radica, međutim, prevodi klerika kao vođu. U prvim člancima navodi prijevod djela kao „Izdajstvo vodja“, a u pripadajućem prikazu spominje „problem opadanja intelektualnih vodja “ $i$,smisao intelektualaca kao vodje “.42 $\mathrm{U}$ drugim člancima će izdajstvu vođa i intelektualcima kao vođama dodati ,izdajstvo uma“ ${ }^{43}$ odnosno „izdajstvo suvremenih duhovnih tendencija, izdajstvo samog duha“. ${ }^{44}$ Pritom će Radica u člancima i kasnije u Agoniji Evrope varirati izdajstvo vođa/izdajstvo intelektualaca. Iako, dakle, Radica misli na intelektualne vođe, nemoguće je odabir te varijante ne povezivati s velikom pozornošću koja se pridavala vođama u politici međuratnog razdoblja, odnosno intelektualcima kao vođama u moderni. Radica će kasnije u svojim uspomenama osvrćući se na Bendu govoriti „o 'izdajstvu duhovnika', o izdajstvu inteligencije, o izdajstvu svakog duhovnog vodstva“" ${ }^{45}$ Izostanak direktnog termina vođe u poslijeratnom kontekstu očito je znak da su termin kompromitirali fašistički i komunistički vođe, kao i da je iščezlo (međuratno) pouzdanje u koncept vođe, bilo političkog, bilo intelektualnog. ${ }^{46}$

Moguće je na kraju postaviti pitanje što je od Bendinih ideja ostalo kod kasnijeg Radice, ima li dugoročnih, formativnih utjecaja? Iako Benda Radici nije bio jedini intelektualac, filozof, umjetnik, književnik koji mu je bio poticajan (nekoliko među njima s kojima je duže razgovarao u Agoniji Evrope bili su mu zasigurno još važniji), dio biografije postajao im je sukladan. Bendino izravnije angažiranje pred Drugi svjetski rat (nakon kritiziranja pristajanja uz desne i lijeve partikularizme), opredjeljivanje za demokraciju nasuprot totalitarizmima, kao i određeno približavanje komunističkom pokretu i odmicanje od njega, nalik je djelomice i Radičinoj putanji. Radica je, naime, u uspomenama, kao što je već spomenuto,

\footnotetext{
$\overline{42}$ B. Radica, „Ideje Juliena Bende“, 52-53.

43 B. Radica, „Izdajstvo uma“, 2.

44 B. Radica, „Konac vječnoga“, br. 145, 2.

45 B. Radica, Živjeti nedoživjeti, 277.

46 Analiza ove epizode s upotrebama termina klerika, intelektualca i vođe figurira kao mala posveta Vjeranu Zuppi (na splitskom fonu ovog zbornika), koji bi navedene pojmove, njihovu etimologiju i dubinska značenja zasigurno još slojevitije interpretirao, kao što je to činio na Desničinim susretima 2013. godine. Usp. Vjeran Zuppa, „Intelektualac: glasine o subjektu (dvanaest marginalija, a trinaesta je umjesto zaključka)“, Intelektualac danas. Zbornik radova s međunarodnog skupa Desničini susreti 2013. (ur. Drago Roksandić i Ivana Cvijović Javorina), Zagreb 2014., 27-37.
} 
navodio kako nije želio u međuratnom razdoblju pristajati uz domaće izrazito angažirane lijeve i desne intelektualce, međutim tijekom rata je izravno podržao antifašistički jugoslavenski pokret, da bi se 1945. godine razočarao i potom napustio komunističku Jugoslaviju, nastavljajući inzistirati na demokraciji kao glavnoj suprotnosti totalitarnim režimima.

Osim, dakle, u svojevrsnim preklapanjima društvenog angažmana, Radica je zadržao u upotrebi ključan Bendin motiv o „silasku na ulicu“ kao izrazu za angažiranje intelektualca. Upotrijebio ga je, primjerice, u otvorenom pismu Miroslavu Krleži iz 1972. godine, kada je tražio da Krleža nakon hrvatskog proljeća zaštiti hrvatske intelektualce (optužujući Krležu za nereagiranje, dakle: za izdaju), predbacujući mu - između niza ostalog - i sljedeće: „Vi

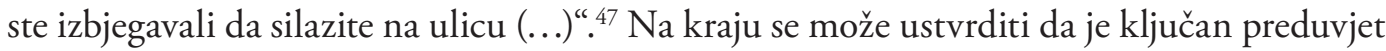
da Radica svoje memoare podnaslovi kao „uspomene hrvatskog intelektualca kroz moralnu i ideološku krizu Zapada“ - odnosno da preuzme na sebe uloge intelektualca - bio u Agoniji Evrope i razgovorima s europskim intelektualcima te njihovim poimanjima intelektualaca, među njima zasigurno i onima Juliena Bende.

\section{MeĐuratno domaće intelektualno polje}

Ako se, dakle, daje uočiti kako je Radica recipirao i koristio Bendine ideje te gledao na problematiku angažmana intelektualaca, moguće je uvidjeti i što je Benda značio za Radicu u kontekstu domaćega intelektualnog polja. U Radičinom slučaju to se, kako je spomenuto, odnosi na pitanje pozicioniranja prema prihvaćanjima ideja fašizma i nacizma, odnosno socijalizma i komunizma. Sam Radica je domaće intelektualno polje (pri čemu navodi Zagreb i Beograd kao središnje točke) vidio rascijepljeno između naginjanja fašističkom ili komunističkom totalitarizmu, kako je izrijekom memoarski isticao.

Pored toga, poseban je izazov pokušati definirati što su konstitutivne odrednice hrvatskog, srpskog ili jugoslavenskog intelektualnog polja u koje Radica i drugi unose Bendu. Povod za to su Bourdieuove napomene kako je - primjerice za autore predgovora - teško biti upoznat s kontekstom polja iz kojeg se preuzima neki autor. Bourdieu ističe da je to zato jer „tekstovi cirkuliraju bez svog konteksta“, odnosno „tekstovi ne nose sa sobom svoj kontekst" $i$,ne donose sa sobom polje proizvodnje“. 48 To se odnosi na tekstove, ideje i autore koje se recipira i unosi, ali i tekstove koji u polju recepcije prenose i uvoze njih same. Kao što Benda ne izvozi sa sobom francuski kontekst, tako ni Radica u svojim tekstovima ne zrcali sveobuhvatno domaći kontekst. U tom smo slučaju upućeni na vlastite rekonstrukcije.

Međutim, ništa nije manje zahtjevno nama danas biti upoznat sa svim nijansama koje čine određeno intelektualno polje u prošlosti, bez obzira bilo ono matično, domaće polje čiji smo kasni odvjetak ili pak proučavatelji. Za istraživače je teško imati sliku cjeline sobzirom da se uvijek fokusiraju na određena istraživačka pitanja. Tako se, na primjer, istraži-

\footnotetext{
47 Bogdan RadicA, „Otvoreno pismo Miroslavu Krleži“, Hrvatska revija, 22/1972., br. 4, 422.

48 P. Bourdieu, „Društveni uvjeti međunarodne cirkulacije ideja“, 114.
} 
vači povijesti intelektualaca u razdoblju između dva svjetska rata fokusiraju na, kao što je već spomenuto, lijeve intelektualce (M. Iveković, Z. Stipetić i drugi) i desne intelektualce (S. Kljajić i drugi). Obrađivani su, primjerice, odnos intelektualaca i socijalističkih i komunističkih ideja, intelektualaca i radničkog pokreta, sukob na književnoj ljevici, angažman lijevih intelektualaca Krleže i Cesarca, intelektualaca uz Hrvatsku seljačku stranku, desnih intelektualaca oko Matice hrvatske, katoličkih intelektualaca, liberalnih intelektualaca itd. Manje je u fokusu, kao što je rečeno, propitivanje jesu li intelektualci sebe poimali intelektualcima i kako su vidjeli vlastitu ulogu kao intelektualaca. U tu se problematiku može prikladno uključiti pristup koji bi intelektualce promatrao u sklopu matičnog intelektualnog polja (u skladu s analizama P. Bourdieua), u koje treba uvrstiti što više različitih aktera. Unutar toga moguće je, naravno, usredotočiti se na niz potpitanja, primjerice: kako su različiti akteri gledali na pojedine inozemne autore?

Radičin pogled na vlastito intelektualno polje - koje je vidio dominantno podijeljenim - tek je, naravno, jedna vizura. Drugačiji je zasigurno Krležin pogled na isto to polje. Tako bi se moglo ići i dalje, uvodeći uvijek nove glasove. Pritom se mogu razmatrati i gledanja domaćih intelektualaca na, primjerice, Bendu. Da je riječ o bitno Radičinoj pojedinačnoj perspektivi, vidljivo je i po tome što, na primjer, Vladan Desnica boraveći u Parizu ne ostavlja tragove o interesu za Bendom i pozornošću koju je izazvao svojom zaoštrenom tezom. ${ }^{49}$ Interes za Bendom nije dakako samorazumljiv i izravno ovisi o vlastitom doživljaju domaćega intelektualnog polja i poimanju potrebe za vlastitim djelovanjem u njemu. Tako se Krleža - prema kojem je Radičin Benda ustvari kritički i uperen - uopće ne referira na Bendu. To je, dakako, razumljivo jer je posve u suprotnosti s Krležinim tipom izravnijeg angažmana, materijalističke inspiracije, što Benda iz idealističke perspektive osuđuje u $I z$ daji intelektualaca. Iz istog je razloga Krleža iznio oštru ocjenu Ortege y Gasseta (koji se, kako smo vidjeli, također protivio izravnom angažmanu intelektualaca): „O Ortegi y Gassetu nikada baš nisam držao mnogo. Njega smo, kao feljtonista, bacili preko palube već prije četrdeset godina, jer čovjek ni jednog trenutka nije imao ni najbljeđeg pojma što je revolucija, a što je socijalizam. ${ }^{\text {"50 }}$

Iz svega toga proizlazi pitanje: koliko različitih perspektiva treba uključiti za rekonstruiranje što šire cjeline nekog intelektualnog polja, kao i tekstova, ideja i autora koji se u njemu recipiraju i upotrebljavaju? To je, dakako, bitno zahtjevnije od usmjeravanja samo na pojedine intelektualce i intelektualne skupine i grupe. Stoga mi ovdje ne preostaje nego iznijeti tek neke natuknice o intelektualnom polju u međuratnoj Hrvatskoj kao dijelu šireg jugoslavenskog prostora. Natuknice koje se ne bave samo idejama intelektualaca, već time kako su u svoje vrijeme shvaćali svoju ulogu i percipirali same intelektualce kao društvenu kategoriju, neovisno od političkih i ideoloških preferencija. Natuknice koje bi išle prema određenoj intelektualnoj povijesti, ne ostajući tako samo na intelektualcima nego i na nekoj vrsti intelektualnog mentaliteta. I na kraju, natuknice koje se uglavnom ne obrađuju.

49 Zahvaljujem Dragi Roksandiću na tom podatku.

50 Miroslav KrležA, „Razgovor o raketama“, Vjesnik (Zagreb), br. 4963, 27. 11. 1960., 6. 
I u tu se problematiku može ući preko Radice, kada je, primjerice, govorio o inteligenciji i poluinteligenciji s periferije. $U$ tome se poziva na Ortegu y Gasseta, koji navodi da u Španjolskoj ,inteligencija neoprezno i naivno unosi i uvodi sve ono što je vidjela, čula ili naučila u inozemstvu“, ističući da je najveći problem „tzv. poluinteligencija“. Radica pritom u razgovoru s Ortegom y Gassetom, na njegove riječi kako poluinteligencija na periferiji samo preuzima tuđe ideje, napominje „da je to i naš slučaj". 51 Treba reći da se u hrvatskom i jugoslavenskom intelektualnom polju u 20. stoljeću često spominjao tip poluinteligenta, odnosno poluinteligencije, što je još jedan od mogućih smjerova obuhvatnijeg istraživanja. Da se pritom pojam inteligencije tada nerijetko koristio u ironičnom i pejorativnom značenju svjedoči i poznati Krležin esej „O našoj inteligenciji“ iz 1927. godine. S obzirom na poimanja intelektualaca, moguće je spomenuti apartan primjer

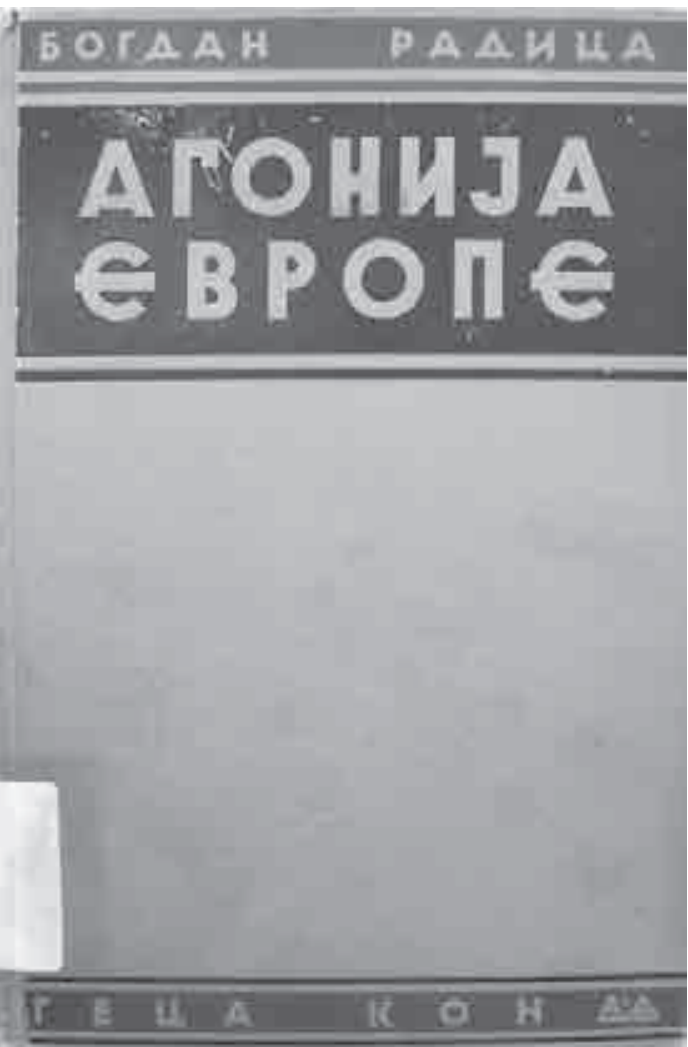

Sl. 3. Prvo izdanje Agonije Evrope (1940.) da je u Beogradu 1934. godine pokrenut časopis Intelektualac, koji nije dugo izlazio, pri čemu sâm časopis zasigurno reprezentira određeni vid poimanja intelektualaca. Vrijedi pritom spomenuti članak „Intelektualci svih profesija ujedinite se“, 52 kao pokušaj da se umjesto ideoloških pitanja u prvi plan stave strukturni problemi zajednički intelektualcima bez obzira na profesiju.

No, dok se ove natuknice (koje čine kontekst cjeline intelektualnog polja u kojem Radica prisvaja Bendu) mahom odnose na poznatija imena ili objavljene tekstove, pravi je izazov doći do anonimnih i neobjavljivanih reakcija. Tako Radica u Agoniji Evrope navodi u razgovoru s Ortegom y Gassetom podatak o domaćim reakcijama s kraja 1930-ih godina na njegovu knjigu Pobuna masa: „Eto jučer sam primio pismo iz vaše zemlje u kojem mi neka dama govori s mnogo smisla i duha o mojoj 'Pobuni masa' i izjavljuje da je ta knjiga koju

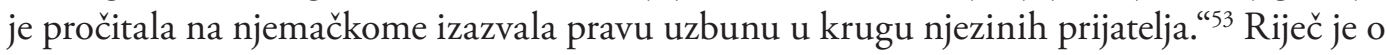
zanimljivim reakcijama koje ništa manje važno ne svjedoče o protežnosti nekog intelektualnog polja i intelektualne povijesti. Osim toga, zanimljivo je što se ne radi samo o reagiranju na društveno-političke okolnosti već i na konkretne strane autore, ideje i djela, uz obavijest

\footnotetext{
B. Radica, Agonija Europe, 168.

52 „Intelektualci svih profesija ujedinite se“, Intelektualac, 1/1934., br. 10.

53 B. Radica, Agonija Europe, 166.
} 
o načinima na koje se to činilo. Iako o takvim i drugim reakcijama ne znamo ništa više od navedenog ili katkad čak ni to, one upozoravaju koliko se toga skriva o nekom intelektualnom polju izvan onoga što nam se čini dominantnim odrednicama promatramo li polje po političkoj podjeli ljevica-desnica ili prema najistaknutijim ličnostima.

\section{Upotrebe BENDE U SUVREMENIM KONTEKSTIMA}

Već spominjana Bourdieuova napomena da „tekstovi cirkuliraju bez svog konteksta“, što znači da „ne nose sa sobom svoj kontekst“, vrijedi dakako za sve kontekste u kojima je upotrebljavan Benda i njegova teza o izdaji intelektualaca. Kao što nije jednostavno razaznati obilježja konteksta iz kojeg dolazi neki inozemni tekst, isto vrijedi i za domaći kontekst u kojem se inozemni tekst recipira i upotrebljava, bez obzira radi li se o daljoj prošlosti (kao u ovom slučaju o međuratnom razdoblju) ili o suvremenim kontekstima koji su nam načelno čak i relativno poznati. Tako se ne može govoriti ni o posve izravnoj vezi između samih tekstova i konteksta u kojima se u suvremenosti nastavio prenositi i upotrebljavati Julien Benda i njegova teza o izdaji intelektualaca. Jasno je, međutim, da protekom vremena dolazi do pomicanja značenja s obzirom na promijenjene okolnosti. Moguće je stoga postaviti pitanja: kako su novi konteksti utjecali na recepcijska čitanja i upotrebe Bende te koliko direktno autori povezuju Bendu s novim kontekstima?

Primjetno je, na primjer, i u poslijeratnom kontekstu da je Julien Benda bio apostrofiran u kontekstu kritike angažirane književnosti. U tom smislu je književnik Danilo Kiš 1970-ih godina isticao da ne vjeruje da „literatura može da služi prosvećivanju, ideologiji, politici...", držeći nasuprot tome da je literatura „sloboda za sebe, sloboda po sebi“. To ilustrira, između ostalog, navođenjem Bende: „Velika izdaja književnika i fariseja počela je onda, kako to kaže Žilijen Benda, kada su pisci postali izmećari vlasti“, želeći da, prema Kišu, „kroz književnost, kroz beletru, da politiziraju, da prosvećuju, što će reći da vladaju“. ${ }^{44}$ Kasnije je kontekst 1990-ih godina dinamizirao značenjske slojeve upotrebe Bende. Pritom je zanimljiva okolnost objavljivanja prijevoda Izdaje intelektualaca na makedonski, srpski i hrvatski jezik baš tih godina. Pitanje koje se odmah nameće jest koliko je riječ o motiviranošću prevođenja dotad neprevedenog klasika, a koliko se radi o pridavanju značenja upravo kao izdaje intelektualaca 1990-ih godina.

Prvo je objavljeno makedonsko izdanje 1992. godine u čijem pogovoru se operacija aktualiziranja vrši vrlo općenito. ${ }^{55}$ Srpsko izdanje Izdaje intelektualaca iz 1996. godine nema predgovor ili pogovor, čime je dakle izostalo eventualno aktualiziranje teze. ${ }^{56} \mathrm{U}$ hrvatskom izdanju iz 1997. godine pogovor Rade Kalanja ne poseže za domaćim kontekstom niti ne

54 Danilo Kıšs, „Doba sumnje“ (http://www.danilokis.org/doba_sumnje.htm).

55 Luan Starova, „Benda i predavstvoto na intelektualcite“, u: Julien Benda, Predavstvoto na intelektualcite, Skopje 1992., 203-210. Uvid u makedonsko izdanje zahvaljujem Michaelu Antoloviću.

56 Na predstavljanju knjige 29. siječnja 1997. u Studentskom kulturnom centru u Beogradu sudjelovali su Ratko Božović, Vladimir Goati, Dragica Vujadinović, Iv Nedeljković i Radul Jovanović. To su podaci koji omogućavaju određenu analizu i pripadajuće zaključke. 
aludira na njega. U prvom planu je prevođenje klasika - 70 godina od objave francuskog izvornika 1927. godine. Međutim, Izdaja intelektualaca u hrvatskom prijevodu objavljena je kao najava knjige prethodno u časopisu Europski glasnik 1997. godine, gdje je u uvodnoj napomeni naglašen upravo aktualizacijski moment:

Knjiga francuskog pisca Juliena Bende (1876-1956) Izdaja intelektualaca, napisana 1926. godine, plaidoyer nezavisnosti intelektualaca od služenja državnim, nacionalnim, moralnim i duhovnim instancama već je klasično i referentno djelo francuske političke filozofije. Za nas ono ima iznimnu aktualnost jer se tiče i domaće atmosfere u kojoj živimo, dapače, u pojedinim dijelovima doima se kao da je napisano za hrvatsko stanje duha; ako bi postojao neki teatar ideja, u njemu bi se iz francuskoga konteksta mogli lako prepoznati likovi i situacije koji tvore današnju Hrvatsku, od opisa državotvornih dušobrižnika do onih koji su upregnuti u suprotne političke strasti. Bendina knjiga razvija, između ostalog, potrebu da se o svome narodu misli i govori slobodno, pokazuje kamo može odvesti poistovjećenje intelektualca s nacijom, i kako ga sukob univerzalnih i partikularnih vrijednosti sili da odustane od svoga istinskoga poziva. ${ }^{57}$

Glavni urednik Dražen Katunarić i retrospektivno je potvrdio kako je objava prijevoda bila motivirana napose naglašavanjem njezine aktualnosti:

Naime, u drugom broju, 1997. godine, „Europski glasnik“ izišao je s programskim tekstom Izdaja intelektualaca Juliena Bende, odnosno aktualizirao jedan od najglasovitijih plaidoyera nezavisnosti intelektualaca od političkoga angažmana. Premda je Benda napisao tu knjigu daleke 1927. godine, on je primjenjiv na mnoge povijesne situacije, a vrlo je aktualan i danas u Hrvatskoj, kad god je riječ o abdikaciji kritičnog mišljenja i slobode koja obuzme inteligenciju. (...) To su neke od programatskih misli koje izriče Benda, ali koje su i credo časopisa. ${ }^{58}$

I recepcijski prikazi prijevoda Bendine knjige završavali su s više ili manje jednakom mjerom aktualizacije. Iako se opsežnije referiraju na specifičnosti Bendine ishodišne argumentacije - i Hrvoje Jurić aktualizira knjigu zaključnom rečenicom: „Bendina Izdaja intelektualaca knjiga je koju danas valja ponovno aktualizirati, ali ne kao lako štivo za intelektualce ili kao kuriozitet u toj vrsti literature, nego kao stalni podsjetnik i bubu u uhu intelektualaca“, 59 što čini i Petar Cvekan završnom rečenicom: „Čitanje ove knjige, zbog njezine prijepornosti i eksplanacijske snage, kategorički je imperativ za svakog intelektualca koji ne želi izdati." ${ }^{\prime \prime 0}$

Prevođenje Bende išlo je, dakle, s jedne strane, logikom prevođenja klasika 70 godina nakon francuskog izvornika, a s druge strane, naglašavanjem njegove aktualnosti. Te su se dvije linije nekad povezivale, a nekad odvajale. No, i u slučajevima kada nije bilo izravnijeg i detaljnijeg referiranja na konkretni domaći kontekst (čime je prepušteno čitateljima da

Europski glasnik, 2/1997., br. 2, 230.

58 Dražen Katunarić, „Za moderno Društvo hrvatskih književnika“, Vijenac (Zagreb), br. 216, 13. 6. 2002., 4-5.

59 Hrvoje Jurić, „Buba u uhu intelektualaca (Julien Benda: Izdaja intelektualaca, Politička kultura, biblioteka Minerva, Zagreb, 1997, prevela Ana Buljan)“, Vijenac (Zagreb), br. 102, 11. 12. 1997., 12.

60 Petar Cvekan, „Julien Benda, Izdaja intelektualaca, Politička kultura, Zagreb, 1997., str. 204“, Politička misao, 34/1997., br. 4, 175. 
sami uočavaju analogije i upisuju značenja), prikladno je pretpostaviti da je kontekst 1990ih godina zasigurno prisutan u tom gotovo simultanom prevođenju u Makedoniji, Srbiji i Hrvatskoj. Svakako se može reći da se očito računalo na važnost prijevoda upravo tog djela i upravo tada, kao i na s time povezani potencijalni interes. Navedeni primjeri neizostavno asociraju na Bourdieuove napomene kako bi trebalo raditi „sociološku komparaciju predgovorâa “. ${ }^{61}$ Jednostavno rečeno, parafrazirajući Bourdieua - recipiranjem i prevođenjem ne dobiva se samo Benda, već Benda s određenim predgovorom, odnosno upotrebom.

Osim, dakle, prijevoda 1990-ih godina i tekstova vezanih uz njih, suvremena upotreba Bende izravno je prisutna i u nizu tekstova i intervjua u kojima Benda nije središnja tema već se spominje usput. Moguće je primjerice izdvojiti intervju književnika Filipa Davida u kojem je naveo sljedeće:

Benda je Izdaju intelektualaca napisao 1927. godine naslućujući dolazak nacizma. Često citiram tu knjigu, to je točno. A kod nas se većina intelektualaca svrstala uz vlast i intelektualci su, u velikom broju, učinili zlo jer su doprinijeli da zločini budu još strašniji, da se riječi izgovorene na nekim tribinama na bojištima pretvore u metke koji su doista ubijali. I trebali bi na neki način odgovarati, ako ne pred sobom i svojom savješću, onda pred nekim sudom. Ako se u Haagu sudi po zapovjednoj odgovornosti, trebalo bi se suditi i intelektualcima. Ili da ih se na neki način lustrira iz društva. Ali ništa se od toga nije dogodilo, oni su i danas ovdje. ${ }^{62}$

Tako i Nikica Mihaljević u svom kritičkom članku o Franji Tuđmanu i hrvatskim književnicima, koji su kao intelektualci pristajali uz ono što naziva tuđmanizmom, koristi Bendu za argumentaciju, čije navode višekratno citira. Značenje koje pripisuje Bendi najvidljivije je u sljedećem:

Kriterij po kojem prosuđujem o zločinačkom karakteru tuđmanizma i o isto takvom značaju angažmana onih hrvatskih književnih inteligenata koji tuđmanizam zagovaraju, promiču i reproduciraju (zarazno, trujući nove naraštaje) jesu stavovi Juliena Bende (1867-1956), francuskoga književnika i filozofa, iz spisa Izdaja intelektualaca („Politička kultura“, Zagreb 1997) i njegova razgovora s Bogdanom Radicom (1904-1993) u knjizi Agonija Evrope (Geca Kon, Beograd 1940). Dakako, na osnovi našega ljevičarskoga svjetonazora i baštini hrvatske ljevice s bardom Miroslavom Krležom na čelu, te Marxovih Ranih radova i tekstova filozofâ Frankfurtske škole, odnosno kritičke teorije, i njihovih nastavljača. No Benda je za našu temu najzahvalniji autoritet jer neposredno, bez uvijanja i kalkuliranja govori o neporecivoj intelektualčevoj izdaji, izdaji vlastite pozicije i misije koju je stoljećima ranije njegovao i izvršavao. ${ }^{63}$

U takvim je primjerima Benda upotrebljavan prvenstveno kritički, uz operaciju aktualiziranja, međutim bez osvrtanja na niz drugih sastavnih dijelova Bendine argumentacije i pripadajućih implikacija. Time se, zapravo, apstrahiraju mnogi slojevi Bendinih ishodišnih stavova koji čine cjelinu s njegovom tezom, a izostaje i problematiziranje eventualnih pro-

61 P. Bourdieu, „Društveni uvjeti međunarodne cirkulacije ideja“, 117.

62 Filip DAvid, „Kulture se moraju prožimati da bi bile zdrave“ (https://procitajto.com/2015/09/19/filip-david-kulturese-moraju-prozimati-da-bi-bile-zdrave/).

63 Nikica Minaljević, „Svjetinu mora netko uvijek nadraživati“ (http://sveske.ba/en/content/svjetinu-mora-netkouvijek-nadrazivati). 
turječja koja proizlaze iz suvremene upotrebe klasičnog djela. Pritom fokus samo na djelo ili katkad samo na tezu, odnosno naslovnu sintagmu, redovito ne ulazi u Bendinu biografiju i mijene njegovih angažmana. Međutim, ti primjeri dobro ilustriraju prevladavajuće naglaske upotrebe Bende u suvremenosti. Potvrđuju svakako i da je suvremena upotreba Bende dinamizirana napose zbog konteksta 1990-ih godina, što je osobito očitovano u povlačenju analogija.

Spomenut ću da sam osobno prvi put za Bendino djelo i tezu o izdaji intelektualaca čuo od Hrvoja Jurića (koji je pisao o knjizi) na tribini na Filozofskom fakultetu u Zagrebu u kontekstu studentske blokade 2009. godine. No, osim primjera upotrebe Bende na uvjetno rečeno ljevici, lako je zamisliti da bi se okrnjena Bendina teza mogla upotrebljavati i u sklopu onog diskursa desnice koji intelektualcima koji kritiziraju domovinu ili ne pokazuju dovoljno domoljublja predbacuju zapravo čin izdaje. To potvrđuje da pregnantna, zaoštrena i univerzalno intonirana Bendina središnja teza o izdaji intelektualaca omogućuje vrlo različite i kontinuirane upotrebe, neovisno o cjelini Bendina poimanja intelektualaca i svijeta u kojem djeluju. Vraćamo se time na napomenu P. Bourdieua kako velika proroštva, značenjski rastezljiva, jako dobro cirkuliraju, kao i da se neki autori upotrebljavaju za ono što bi sami nerijetko osudili.

Iako su u međuvremenu oblikovane mnoge razrade problematike uloge intelektualaca (kao što su to učinili Gramsci, Mannheim, Sartre, Foucault, Bourdieu, Said i drugi), ${ }^{64}$ snaga i privlačnost Bendine sintagme i dalje joj osiguravaju kontinuiranu prisutnost u javnom govoru te ju čine bitno raširenijima od drugih poimanja intelektualaca. Premda je o intelektualcima izneseno u 20. stoljeću mnogo slojevitijih tumačenja - Bendino je iz suvremene perspektive suviše idealističko - očito je da recepcije i upotrebe idu nekim svojim, kontekstualno određenim, logikama. Time Benda ujedno pruža vrlo ilustrativan primjer razumijevanja općih mehanizama recepcije i aproprijacije. Zaključiti stoga možemo naknadnim odgovorom samom Bendi na njegovo pitanje iz naslova rada: „Vi na Balkanu to sve znate i čitate?!“. Ne samo da se poznavalo i čitalo, već se njegovo djelo, osobito središnja teza, uvijek iznova upotrebljavalo.

64 Usp. Branimir Janković, „Prema historiji intelektualaca i intelektualnoj historiji“, Intelektualna historija (prir. Branimir Janković), Zagreb 2013., 19-48. 


\section{$\cos$}

\section{"You in the Balkans Know and Read All This": Reception and Uses of Julien Benda and His THE TREASON OF THE INTELLECTUALS}

The Treason of the Intellectuals, the famous work by Julien Benda, published in 1927, is one of the most well-known works discussing the role of intellectuals, especially for its radical thesis that intellectuals betrayed their universal mission because of their excessive commitment to the state, nation, race and class. Benda's work and its main thesis had a strong impact in Croatia and the region over the course of the $20^{\text {th }}$ century, and all the way up to the present. Immediately upon its original publication Bogdan Radica wrote extensively about it in Yugoslavia in the 1920s and 1930s. For Radica Benda meant the opportunity to bolster his own political positioning between the two totalitarianisms, that is, to examine a more direct form of social activism in the period before WW II. After the interwar period, the reception and appropriation of Benda was especially intensive in the 1990s. That period saw the publication of Macedonian, Serbian and Croatian editions of The Treason of the Intellectuals. To translate Benda then meant to translate a classic text that had not been translated in the 70 years since the original French publication, but it also meant an occasion for emphasizing his relevance, especially as regards the role and responsibility of intellectuals in the war and the transition in the 1990s. In that regard, Benda's central thesis on the betrayal of the intellectuals proved to be exceptionally suitable for continued interpretation and uses in ever new contexts. In this light, it is possible to analyse some features of the domestic intellectual field and intellectual history both in the period between the two World Wars and in the contemporary period. To conceptualize and interpret the mentioned matters and problems generally, the insights of the French sociologist Pierre Bourdieu on the "social conditions of the international circulation of ideas" have proven particularly useful. Thus, dealing with the reception and uses of Julien Benda and his work offers an illustrative example of understanding the general mechanisms of reception and appropriation of texts, ideas and authors.

Key words: intellectuals, treason of the intellectuals, Julien Benda, Bogdan Radica, reception, use, Pierre Bourdieu

\section{$\cos$}

\section{Literatura}

Ivo Banac, „Bogdan Radica - agonija i borba“, u: Bogdan Radica, Agonija Europe. Razgovori i susreti, Zagreb 2006., 371-377.

Julien BENDA, „Izdaja intelektualaca“, Europski glasnik, 2/1997., br. 2, 230-327.

Julien BENDA, Izdaja intelektualaca, Zagreb 1997.

Pierre Bourdieu, „Društveni uvjeti međunarodne cirkulacije ideja“, Intelektualna historija (prir. Branimir Janković), Zagreb 2013., 112-123.

Antoine Compagnon, Les antimodernes. De Joseph de Maistre à Roland Barthes, Paris 2005.

Petar Cvekan, „Julien Benda, Izdaja intelektualaca, Politička kultura, Zagreb, 1997., str. 204“, Politička misao, 34/1997., br. 4, 172-175. 
Filip DAvid, „Kulture se moraju prožimati da bi bile zdrave“ (https://procitajto.com/2015/09/19/ filip-david-kulture-se-moraju-prozimati-da-bi-bile-zdrave/).

Stevo ĐurašKović, „Bogdan Radica - nacionalist, liberal i kozmopolit istodobno“, u: Bogdan Radica, Agonija Europe. Razgovori i susreti, Zagreb 2006., 379-385.

Mladen Iveković, Hrvatska lijeva inteligencija 1918-1945., Zagreb 1970.

Milosav Janićijević, Stvaralačka inteligencija meduratne Jugoslavije, Beograd 1984.

Branimir JANKović, „Prema historiji intelektualaca i intelektualnoj historiji“, Intelektualna historija (prir. Branimir Janković), Zagreb 2013., 11-77.

Hrvoje Jurić, „Buba u uhu intelektualaca (Julien Benda: Izdaja intelektualaca, Politička kultura, biblioteka Minerva, Zagreb, 1997, prevela Ana Buljan)“, Vijenac (Zagreb), br. 102, 11. 12. 1997., 12.

Rade Kalanj, „Uvijek prijeporni Benda“, u: Julien Benda, Izdaja intelektualaca, Zagreb 1997., 190-203.

Dražen Katunarić, „Za moderno Društvo hrvatskih književnika“, Vijenac (Zagreb), br. 216, 13. 6. 2002., 4-5.

Danilo KIš, „Doba sumnje“ (http://www.danilokis.org/doba_sumnje.htm).

Stipe KlJAjIĆ, Intelektualci i hrvatski nacionalizam (1929. - 1945.), doktorski rad, Zagreb 2015.

Miroslav KrležA, „Razgovor o raketama“, Vjesnik (Zagreb), br. 4963, 27. 11. 1960., 6.

Stanko Lasıć, Krležologija ili povijest kritičke misli o Miroslavu Krleži, sv. 6, Zagreb 1993.

Nikica Minaljević, „Svjetinu mora netko uvijek nadraživati“ (http://sveske.ba/en/content/svjetinu-mora-netko-uvijek-nadrazivati).

Engel Pascal, „Julien Benda et le culte de l'universel“, Le Philosophoire, 1/2009., br. 31, 147-148.

Bogdan Radica, Agonija Europe. Razgovori i susreti, Zagreb 2006.

Bogdan Radica, Agonija Evrope. Razgovori i susreti, Beograd 1940.

Bogdan RadicA, „Ideje Julijena Bende“, Savremenik, 21/1928., br. 2, 50-55.

Bogdan RadicA, „Izdajstvo uma“, Obzor (Zagreb), br. 74, 15. 3. 1928., 2-3.

Bogdan RadicA, „'Izdajstvo vođa’ (Svedočanstvo najmlađih)“, Nova Evropa, 18/1928., br. 6, 186189.

Bogdan RadicA, „Konac vječnoga. Teza Juliena Bende i protest Jeana Guéhenna“, Novo doba (Split), br. 145, 10. 6. 1929., 2, 7; br. 146, 11. 6. 1929., 2.

Bogdan Radica, „Otvoreno pismo Miroslavu Krleži“, Hrvatska revija, 22/1972., br. 4, 422.

Bogdan RadicA, Živjeti nedoživjeti, knj. 1: Uspomene hrvatskog intelektualca kroz moralnu i ideološku krizu Zapada, München - Barcelona 1982.

Razgovor o Europi. Kulturno-politički eseji francuskih pisaca (prir. Ivo Hergešić), Zagreb 1944. Zorica STIPETIĆ, Komunistički pokret i inteligencija. Istraživanja ideološkog i političkog djelovanja inteligencije u Hrvatskoj (1918-1945), Zagreb 1980.

Luan Starova, „Benda i predavstvoto na intelektualcite“, u: Julien Benda, Predavstvoto na intelektualcite, Skopje 1992., 203-210.

Vjeran ZupPA, „Intelektualac: glasine o subjektu (dvanaest marginalija, a trinaesta je umjesto zaključka)“, Intelektualac danas. Zbornik radova s međunarodnog skupa Desničini susreti 2013. (ur. Drago Roksandić i Ivana Cvijović Javorina), Zagreb 2014., 27-37. 